\title{
Numerial Analysis of Elastic-Plastic Deformation of Simply Supported Rectangular Plates
}

\author{
by Yoshitsura YOKOO*, Tsuneyoshi NAKAMURA** and \\ Takeo MORI***, Members of A.I.J.
}

\section{Introduction}

Previous investigations on the analysis of plastic plates may be divided into two categories. The limit analysis determines the stress and velocity fields at plastic collapse together with the collapse load, provided a complete solution is obtained. Number of lower and upper bounds on the collapse load of a rectangular plate have been obtained [1]. The elastic-plastic analysis is concerned with the process of elastic-plastic deformation and with the variation of stress fields as the load is varied. Previous analytical works in the latter category have been restricted to rotationally symmetric problems of plates. The difficulties in the elastic-plastic analysis of a rectangular plate lie not only in the set of nonliner moment curvature-rate relations, but also in the unknown elastic-plastic interfaces as the load is varied.

This paper presents the result of a numerical analysis of elastic-plastic deformation of simply supported rectangular plates subjected to uniformly distributed load. While the present work has been carried out, Bhaumik and Hanley [2] presented a numerical work for a square plate which does not appear to be based upon the incremental theory. In March 1968 when the present work was completed as the junior author's M. Eng. thesis [6], the numerical result by Ang anp Lopez [3] which is based upon the incremental theory came to the authors' attention. Although the numerical method based upon the stiffness matrix concept [4] has been employed with different derivations but essentially in a similar fashion in both works, Ang and Lopez is concerned only with a square plate, whereas the present work deals with rectangular plates.

\section{Fundamental Equations in Incremental Form}

The following assumptions are made in this paper.

(i) The moment-curvature relationship for a plate element is governed by the incremental theory.

(ii) An element of a plate is either elastic or plastic. No transitional state is taken into account. This implies that the plate is assumed to be an idalized sandwich plate with a shear-resistant core.

(iii) The displacement is so small that membrane forces are negligible.

(iv) The moment and displacement fields are continuous and have continuous derivatives up to the second order so that the differential equations may be approximated by the corresponding finite difference equations. Theoretically admissible discontinuities may be averaged and smoothedin applying the finite difference procedure.

The dimensionless coordinate axes are chosen as shown in Fig. 1, where. $x=X / L, y=Y / L, L$ being a side length of a plate. The

following dimensionless quantities are employed here.

$$
m_{x}=\frac{M_{x}}{M_{0}} \text {, etc. ; } p=\frac{P L^{2}}{6 M_{0}}, w=\frac{W}{H}, k_{x}=\frac{K_{x} L^{2}}{H}, \text { etc. } \cdots(1)
$$

where $H$ denotes the plate thickness and $P$, the distributed load in the positive $W$ direction.

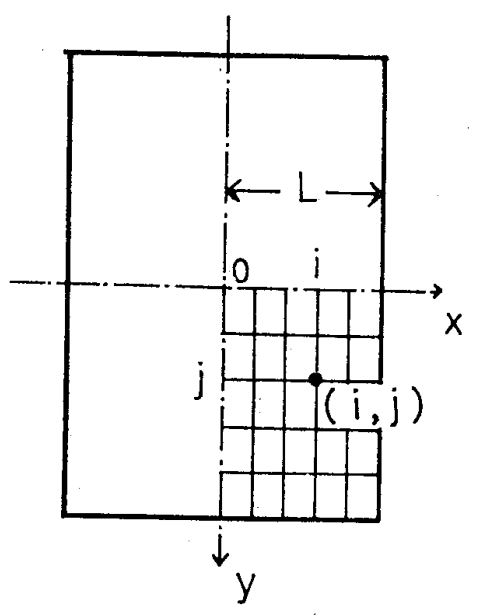

Fig. 1 
The von Mises yield condition for a plate element may be written as

$$
f\left[m_{x}, m_{y}, m_{y}\right]=m_{x}{ }^{2}-m_{x} m_{y}+m_{y}{ }^{2}+3 m_{x y}{ }^{2}-1=0
$$

It is assumed that the actual curvatures $k_{x}$, etc. may be written as the sum of the elastic curvature $k_{x}{ }^{e}$, etc. and the plastic curvature $k_{x}{ }^{p}$, etc. The plastic potential flow law gives

$$
\dot{k}_{x} p=\dot{\mu} \frac{\partial f}{\partial m_{x}}, \quad \dot{k}_{x y}{ }^{p}=\dot{\mu} \frac{\partial f}{\partial m_{x y}}, \quad \dot{k}_{y}^{p}=\dot{\mu} \frac{\partial f}{\partial m_{y}}
$$

where

$$
\begin{aligned}
& \dot{\mu}=0 \text { if } f<0 \text { and also if } f=0 \text { and } \dot{f}<0 \\
& \dot{\mu} \geq 0 \text { if } f=0 \text { and } \\
& \dot{f}=\left(2 m_{x}-m_{y}\right) \dot{m}_{x}+6 m_{x y} \dot{m}_{x y}+\left(2 m_{y}-m_{x}\right) \dot{m} y=0
\end{aligned}
$$

Let " $\Delta$ " denote a finite difference operator with respect to time or any other parameter which increases monotonically with time. The curvature increments are the sum of the elastic and plastic curvature increments.

$$
\begin{aligned}
& \Delta k_{x}=\frac{1}{C\left(1-\nu^{2}\right)} \Delta m_{x}-\frac{\nu}{C\left(1-\nu^{2}\right)} \Delta m_{y}+\frac{1}{C(1-\nu)}\left(2 m_{x}-m_{y}\right) \Delta \mu \\
& \Delta k_{x y}=\frac{1}{C(1-\nu)} \Delta m_{x y}+\frac{1}{C(1-\nu)} 6 m_{x y} \Delta \mu \\
& \Delta k_{y}=-\frac{\nu}{C\left(1-\nu^{2}\right)} \Delta m_{x}+\frac{1}{C\left(1-\nu^{2}\right)} \Delta m_{y}+\frac{1}{C(1-\nu)}\left(2 m_{y}-m_{x}\right) \Delta \mu
\end{aligned}
$$

where

$$
C=\frac{D H}{M_{0} L^{2}}
$$

$$
\}
$$

The inversion of Eqs. (5) may be found with the help of Eq. (4).

The result may be written as

$$
\left[\Delta m_{x}, \Delta m_{x y}, \Delta m_{y}, \Delta \mu\right]^{T}=\left[S_{i j}\right]\left[\Delta k_{x}, \Delta k_{x y}, \Delta k_{y}\right]
$$

The fourth row of $\left[S_{i j}\right]$. which does not consist of stiffness quantities has been included in $\left[S_{i j}\right]$ for convenience.

The stiffness matrices $\left[S_{i j}\right]$ are

$$
C\left(\begin{array}{ccc}
1 & 0 & \nu \\
0 & 1-\nu & 0 \\
\nu & 0 & 1 \\
0 & 0 & 0
\end{array}\right), \quad \frac{C(1-\nu)}{S}\left(\begin{array}{ccc}
(1+\nu) F^{2}+G^{2} & -(E+\nu F) G & -(1+\nu) E F+\nu G^{2} \\
-G(E+\nu F) & E^{2}+2 \nu E F+F^{2} & -G(F+\nu E) \\
-(1+\nu) E F+\nu G^{2} & -(F+\nu E) G & (1+\nu) E^{2}+G^{2} \\
E+\nu F & (1-\nu) G & F+\nu E
\end{array}\right)
$$

for an elastic response and a plastic response, respectively, where

$$
E=2 m_{x}-m_{y}, \quad G=6 m_{x y}, \quad F=2 m_{y}-m_{x}
$$

and

$$
S=E^{2}+2 \nu E F+F^{2}+(1-\nu) G^{2}
$$

The incremental equations of equilibrium

$$
\frac{\partial^{2} \Delta m_{x}}{\partial x^{2}}+2 \frac{\partial^{2} \Delta m_{x y}}{\partial x \partial y}+\frac{\partial^{2} \Delta m_{y}}{\partial x^{2}}+6 \Delta p=0
$$

may be reduced to the finite difference equations.

$$
\begin{aligned}
& \Delta m_{x}(i-1, j)-2 \Delta m_{x}(i, j)+\Delta m_{x}(i+1, j) \\
& +\frac{2 \alpha}{4}\left[\Delta m_{x y}(i-1, j-1)-\Delta m_{x y}(i-1, j+1)-\Delta m_{x y}(i+1, j-1)+\Delta m_{x y}(i+1, j+1)\right] \\
& +\alpha^{2}\left[\Delta m_{y}(i, j-1)-2 \Delta m_{y}(i, j)+\Delta m_{y}(i, j+1)+24 \delta_{x}^{2} \Delta p=0\right.
\end{aligned}
$$

where $\delta_{x}=\alpha \cdot \delta_{y} \delta_{x}$ and $\delta_{y}$ being the mesh lengths in $x$ and $y$ directions, respectively.

The incremental kinematic relations

$$
\Delta k_{x}=-\frac{\partial^{2} \Delta w}{\partial x^{2}}, \Delta k_{x y}=-\frac{\partial^{2} \Delta w}{\partial x \partial x}, \Delta k_{y}=-\frac{\partial^{2} \Delta w}{\partial y^{2}}
$$


are also replaced by the finite difference equations:

$$
\begin{aligned}
\Delta k_{x} & =-\frac{1}{\delta_{x}^{2}}[\Delta w(i-1, j)-2 \Delta w(i, j)+\Delta w(i+1, j)] \\
\Delta k_{x y} & =-\frac{\alpha}{4 \delta_{x}^{2}}[\Delta w(i-1, j-1)-\Delta w(i+1, j-1)-\Delta w(i-1, j+1)+\Delta w(i+1, j+1)] \\
\Delta k_{y} & =-\frac{\alpha^{2}}{\delta_{x}^{2}}[\Delta w(i, j-1)-2 \Delta w(i, j)+\Delta w(i, j+1)]
\end{aligned}
$$

The boundary conditions along a simply supported edge, say $x=$ const. may be written as

$$
\Delta w=0 \text {, and } \Delta m_{x}=0
$$

At an elastic or unloading boundary point, the latter equation of (12) may be replaced by

$$
\Delta k_{x}=0
$$

At a plastic boundary point, the first and second equations of (6) may be written as

$$
\Delta m_{x}=S_{11} \Delta k_{x}+S_{12} \Delta k_{x y}=0, \Delta m_{y}=S_{31} \Delta k_{x}+S_{32} \Delta k_{x y}
$$

Since $m_{x}=m_{y}=0$ in the elastic state, $S_{12}=S_{32}=0$ and hence, for all the subsequent loading step, $\Delta k_{x}=0$ and $\Delta m_{y}=0$ except possibly at a point where $S_{11}=0$, implying $m_{x y}=0$. Because of the assumed continuity in $\Delta k_{x}, \Delta k_{x}=0$ for all the plastic boundary points. Therefore the finite difference form of the boundary conditions may be written as

$$
\Delta w(b, j)=0, \quad \Delta w(b+1, j)+\Delta w(b-1, j)=0
$$

where " $b$ " denotes a boundary mesh point. At a corner point the condition

$$
\Delta w(b+1, b+1)=\Delta w(b-1, b-1)
$$

is postulated by assuming a checker-board displacement pattern for the imaginary exterior plate region.

Eqs. (6), (9) and (11) together with (13) and (14) constitute a system of simultaneous linear algebraic equations for $\Delta w(i, j)$ if the preceding state of moments is known. If a successive forward integration procedure is repeated with respect to some appropriate load increments, then the elastic-plastic response of a plate may be numerically traced by a piecewise linear approximation.

\section{Computational Procedure}

As the load intensity is increased beyond the elastic limit, the number of plastic grid points will increase gradually. The elastic-plastic interfaces at different load levels will form different contours which must be found as a part of the solution.

A plastic grid point must have experienced a transition step in which the previously elastic point becomes plastic for the first time. Where the response to a predetermined load increment is elastic throughout the increment or plastic partially is not known a priori. Hence it seems convenient to choose a load increment such that no new transition occurs during that increment and such that at least one previously elastic point will have just satisfied the yield condition at the end of the increment. Let $m_{x}(i, j, n)$, etc. be the moments at the end of $n$-th step. Let $\Delta m_{x}(i, j, n+1)$, etc. denote the moment increments for a unit load increament obtained from the new stiffness matrix for the $(n+1)$-st step. Then the load increment $\Delta p(n+1)$ for the $(n+1)$-st step may be determined as the minimum of $\Delta p(i, j, n+1)$ which satisfies

$$
\begin{aligned}
& f\left[m_{x}(i, j, n)+\Delta \bar{p}(i, j, n+1) \Delta m_{x}(i, j, n+1), m_{x y}(i, j, n)\right. \\
& \left.\quad+\Delta \bar{p}(i, j, n+1) \Delta m_{x y}(i, j, n+1), m_{y}(i, j, n)+\Delta \bar{p}(i, j, n+1) \Delta m_{y}(i, j, n+1)\right]=0 \cdots
\end{aligned}
$$

A forward integration step consists of the following computational substeps.

(i) Determine the stiffness matrix for each grid point from the previous values of moments.

(ii) Compute the coefficients of the finite difference equations for $\Delta w(i, j)$.

(iii) Solve the system of simultaneous linear algebraic equations for $\Delta p=1$ and obtain $\Delta w(i, j)$.

(iv) Compute $\Delta \mu(i, j)$ for all the grid points. If $\Delta \mu(i, j)<0$ for somegrid points, then replace the corresponding plastic stiffness matrix by the elastic one for that grid point at which $\Delta \mu(i, j)$ is the smallest negative. Then return to (ii).

(v) If $\Delta \mu(i, j)>0$ for all the grid points, then determine the actual load increment $\Delta p(n+1)$ in 
accordance with Eq. (15).

(vi) Compute the moment increments corresponding to $\Delta p(n+1)$ and add them respectively to the previous moment values, and then return to (i)

In order to avoid the circumstance in which the coefficient matrix of step (iii) becomes nearly singular as plastic grid points prevail, the solution for a prescribed displacement $\Delta w(0,0)=1$ is obtained instead of step (iii).

\section{Numerical Results}

Numerical solutions have been obtained for rectangular plates with the side length ratio or span

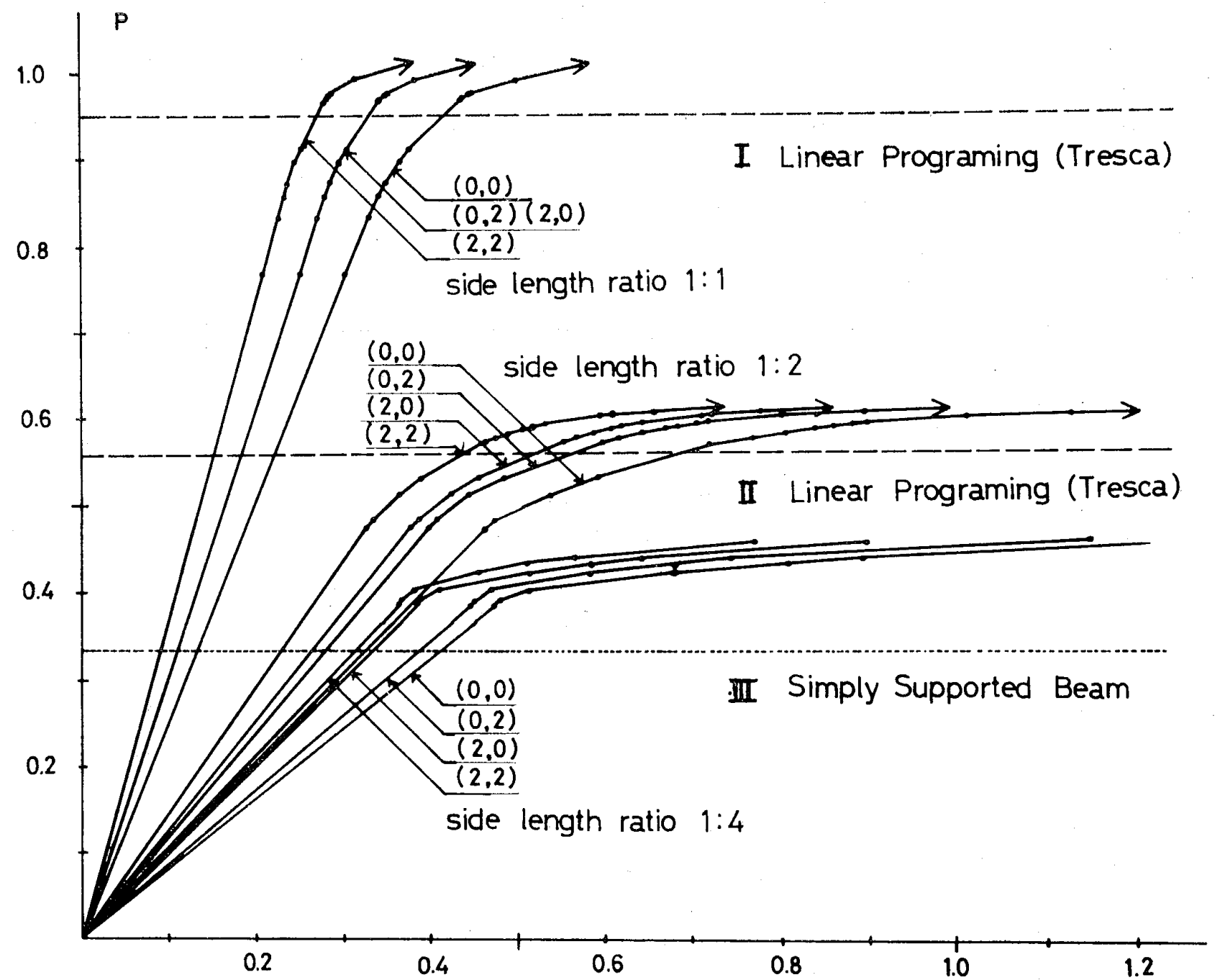

Fig. 2
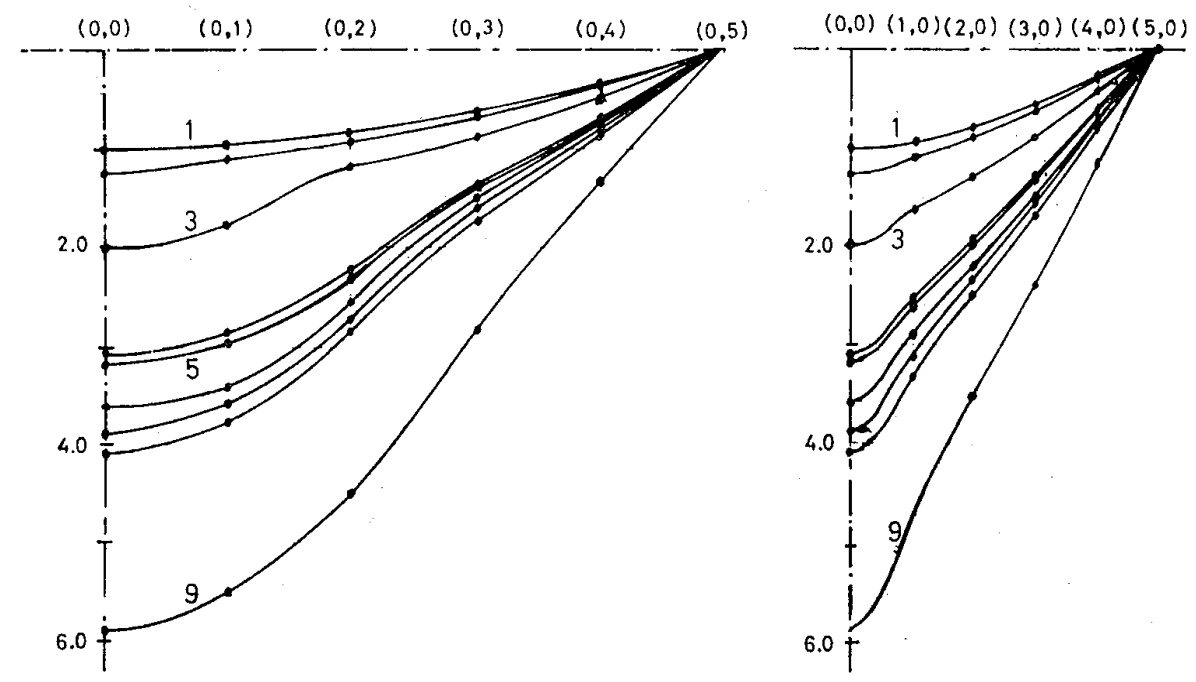

Fig. 3 
length ratio $1 / \alpha=1,2$ and 4 for $C=1.0$ and $\nu=0.3$. The mesh sizes for plates with $1 / \alpha=1,2$ and 4 were chosen respectively as $\left(\delta_{x}, \delta_{y}\right)=(0.2,0.2),(0.2,0.4)$ and $(0.2,0.8)$. Fig. 2 shows the loaddisplacement curve for several mesh points fo plate of $1 / \alpha=2$. The broken lines $I$ and $I$ indicate the corresponding lower bounds on the collapse loads obtained by the present authors by means of the linear programming technique (proposed by Koopman and Lance [5]) for the case of linearized Tresca polyhedron consisting of 16 planes. The dotted line III indicates the collapse load of a beam of unit width. Fig. 3 shows the displacement patterns along the axes, for uniformly distributed unit toad. It is observed that the displacement becomes greater for the same load as the plastic mesh points increase.

Fig. 4 shows the order of yielding of mesh points. No unloading response was obtained for plates with $1 / \alpha=2$ and 4 . For a square platte, however, unloading responses occurred in the 6th step at $(0,0)$ and in the 9 th and 10th step at $(1,0)$ and $(0,1)$. Although the computational outputs show unloading responses under compatible stiffness matrices, the resulting values of the yield function have never become less than -0.01 which is the computational tolerance limit. The plastic region for a square plate is developed from the corners and then from the center, whereas the plastic region for rectangular plates $1 / \alpha=2$ is first developed from the center parallel to the longer side and then also from the corners. It has been pointed out by Ang and Lopez that overall stiffness of a square plate, as indicated by the slope of the load-displacement curve, decreases considerably when a pseudo-mechanism is for-
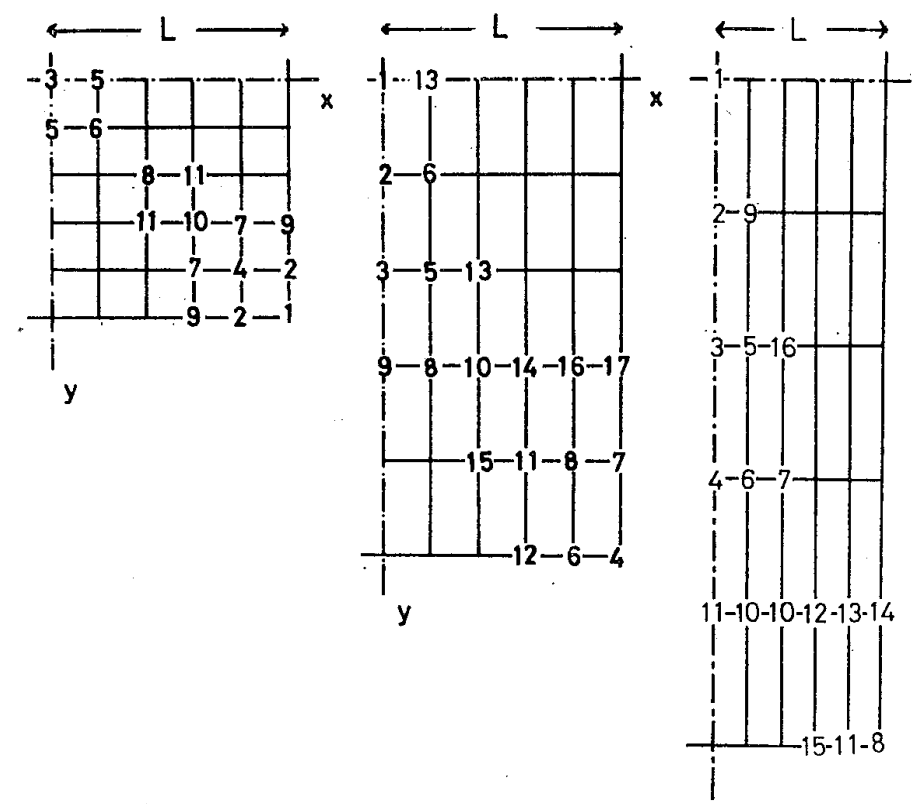

Fig. 4
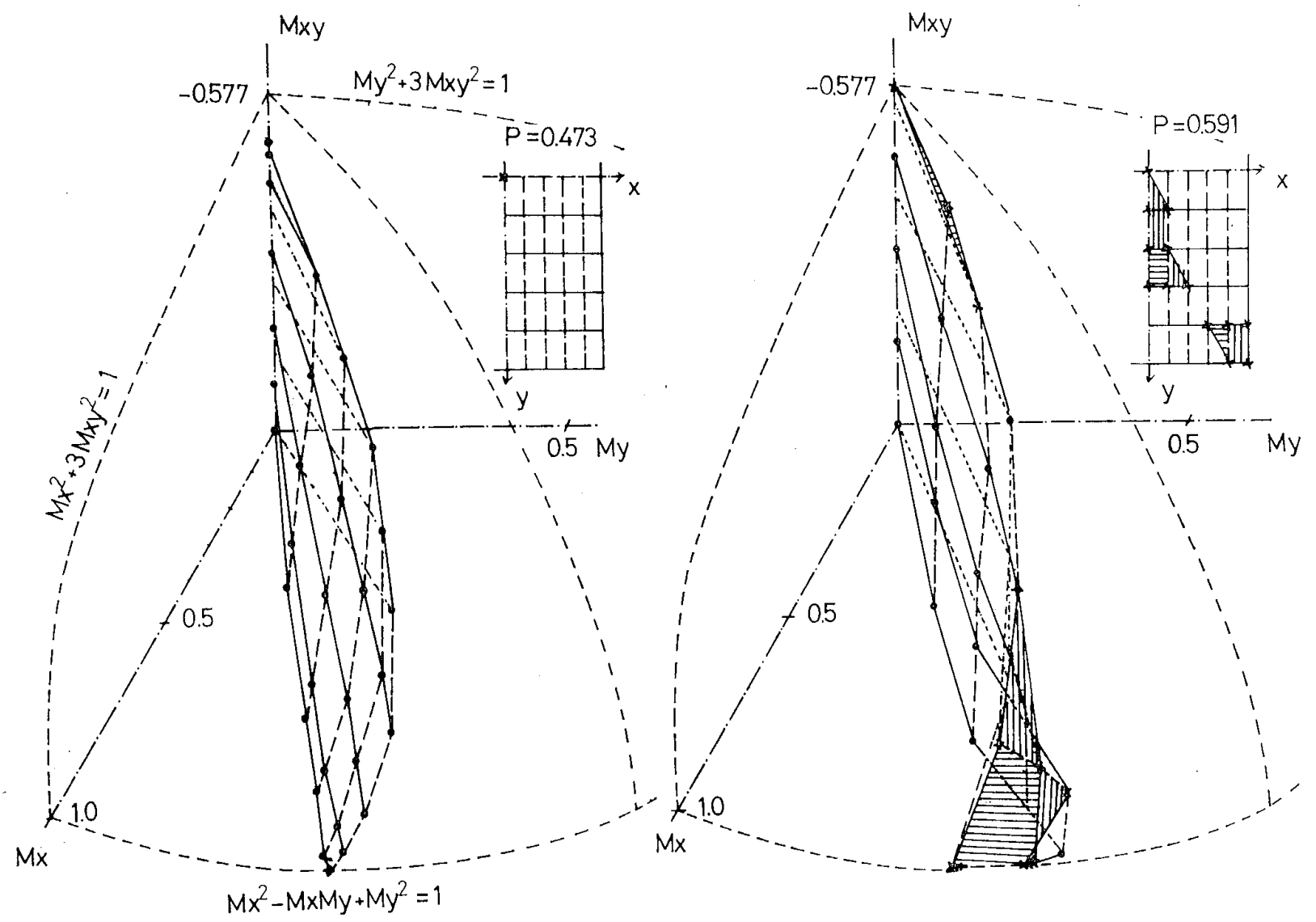

Fig. 5 

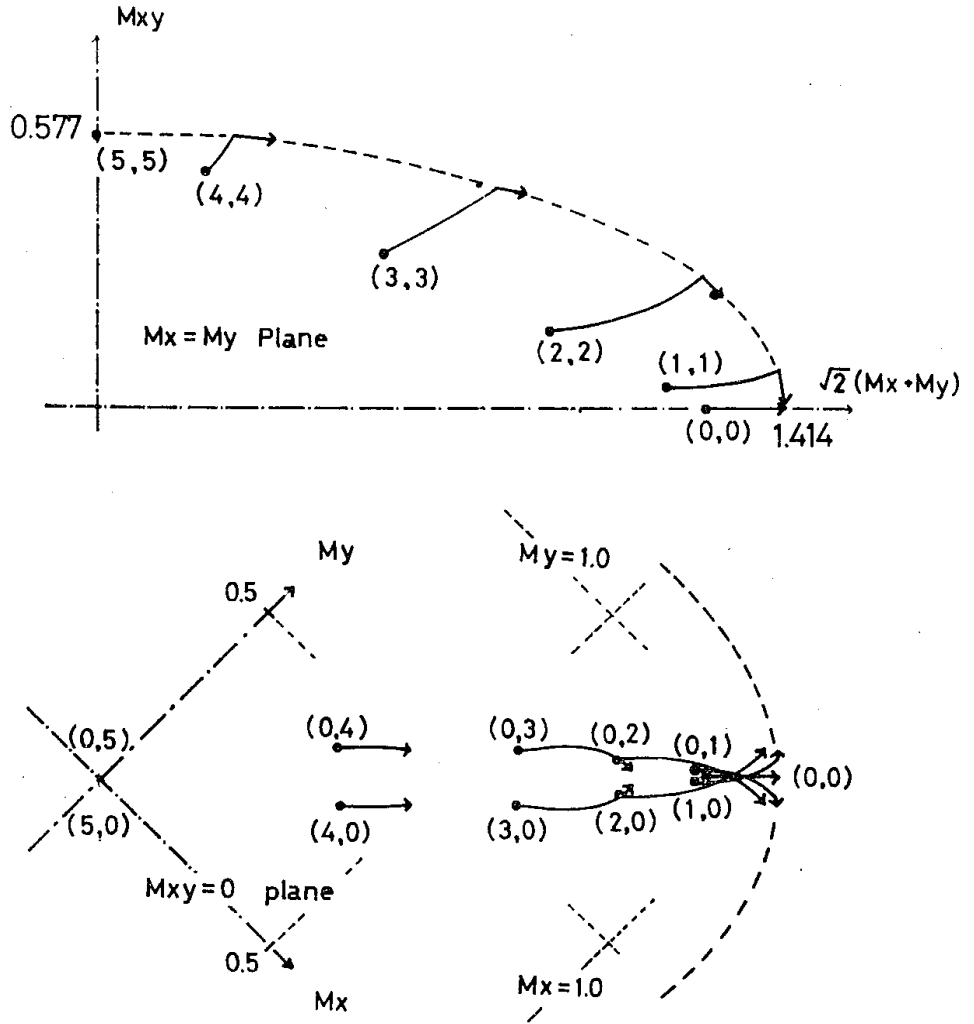

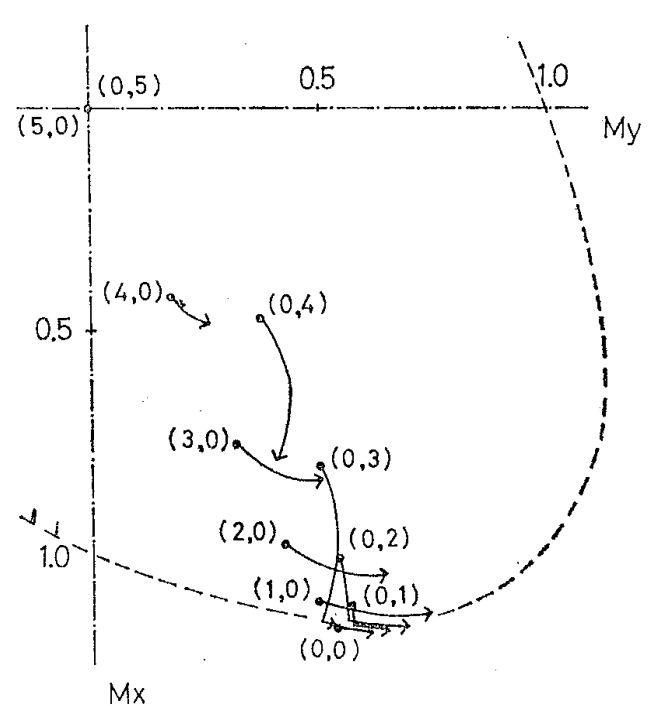

Fig. 7

Fig. 6

med by the plastic region. In a rectangular plate, however, the overall stiffness decreases considerably already when the oblong plastic region is developed at the center of the plate as may be also seen from Fig. 3.

Fig. 5 shows the stress surfaces at $p=0.473$ (the elastic limit) and at $p=0.591$ in a $\left(m_{x}, m_{x y}, m_{y}\right)-$ space for the plate with $1 / \alpha=2$. The broken lines indicate the intersection of the yield surface with the coordinate planes and with $m_{x}=m_{y}$.

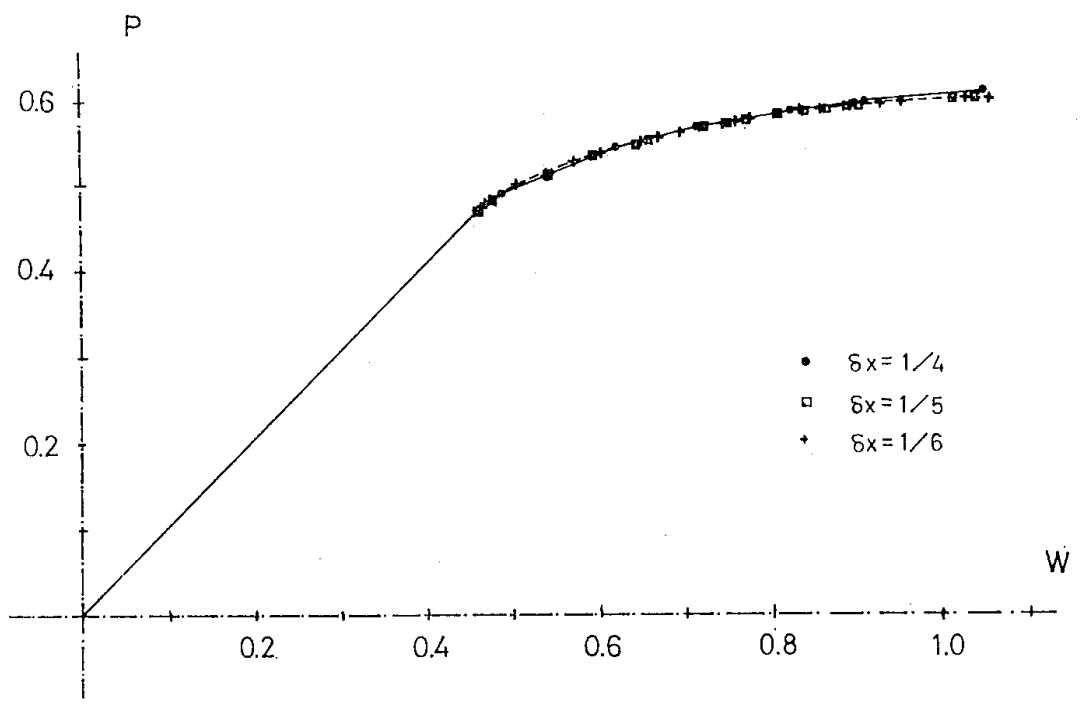
The plastic mesh points are indicated by $*$ and the hatched portions show the plastic regions. These stress sufaces will give some idea how the stress surface is inflated, expanded and approches the yield surface from inside as the plastic region grows greater. Fig. 6 and 7 show some stress point paths for those mesh points which are known a priori to remain in $m_{x y}=0$ and $m_{x}=m_{y}$ for the plates with $1 / \alpha=1$ and 2 , respectively.

In order to investigate the influence of mesh size on the numerical result, the three different solutions based upon the mesh sizes $\left(\delta_{x}, \delta_{y}\right)=(0.25,0.50),(0.2,0.4)$ and $(0.167,0.333)$ are compared for the plate with $1 / \alpha=$ 2. Fig. 8 shows the load-displacement curves for the mesh point $(0.0)$. It is noted that no significant di-

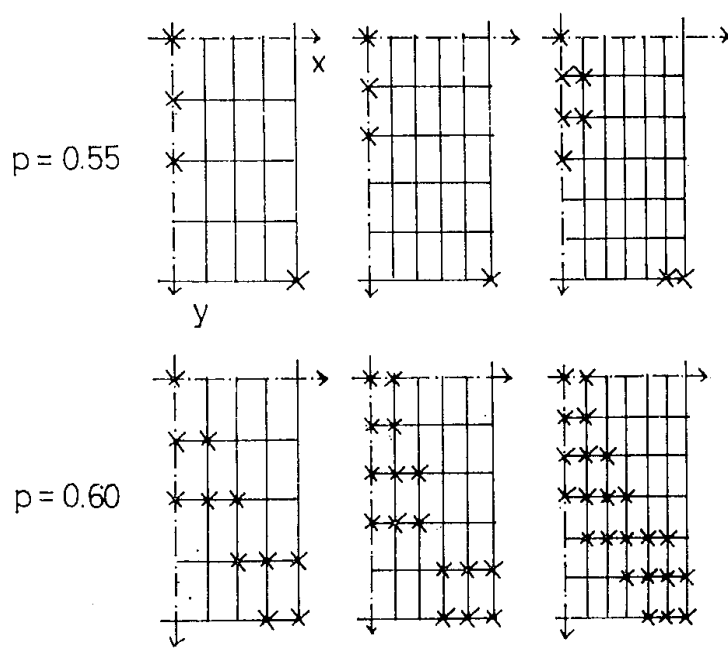

Fig. 9 
fference is observed in these curves. The plastic regions at $p=0.55$ and $p=0.60$ are also compared for these three cases in Fig. 9. Fig. 8 and 9 and the numerical results for these three cases provide a numerical assurance on the convergence of the present numerical analysis.

\section{Conclusion}

The following conclusions may be drawn from the result.

(i) A simple forward integration procedure with respect to incremental load on the spatial finite difference equations furnishes numerical solutions with numerical assurance on the convergence of the procedure.

(ii) The plastic region in a rectangular plate with $1 / \alpha=2$ is developed first from the center parallel to the longer side and then also from the corners, whereas the plastic region in a square plate is developed, first from the corners and then from the center along the diagonals. The central portion in a narrow rectangular plate behaves like a very wide beam with the shorter span length. The well developed plastic region in a narrower rectangular plate which may be called to have formed a pseudo-mechanism, has a narrow band parallel to the longer side.

(iii) The slope of the load-displacement curve for a rectangular blate decreases considerably already when the oblong plastic region is developed at the center. The increment of load from the elastic limit to the state of well-developed plastic region decreases as $1 / \alpha$ becomes longer.

(iv) The stress point for a plastic mesh point travels in an $\left(m_{x}, m_{x y}, m_{y}\right)$ spase, on the Mises yield surface. This implies that the state of moments changes after yielding. The redistribution of moments at a plastic grid point in a square plate occurs in such a way that $m_{x y}$ decreases whereas $m_{x}+m_{y}$ increases. In a rectangular plate, on the other hand, the stress points within the narrower triangle with respect to the diagonals move toward the yield surface comparatively rapidly and travel after yielding, on the yield surface in such a way that $m_{x y}$ decreases whereas $m_{x}+m_{y}$ increases. The stress points within the wider triangles approach the yield surface rather slowly. The inflation or expansion of the stress surface inside the yield surface is quite complicated as the plastic region is developed.

\section{Acknowledgement}

The authors are grateful to Mr. H. Matsunaga for his helpful suggestions in the computational procedures. The present numerical work was carried out on the KDC-II computor of Kyoto University Computation Center.

\section{References}

[1] For instance, H.E. Shull and H.W.Hu, "Load Carrying Capacities of Simply Supported Rectangular Plates”, Journal of Applied Mechanics, ASME, Dec. 1963, pp. 617-621.

[2] A.K. Bhaumick and J.T. Hanlay, "Elasto-Plastic Plate Analysis by Finite Difference Methods", Journal of Structural Division, ASCE, Oct. 1967, pp. 279-293.

[3] A.H.S. Ang and L.A. Lopez, "Discrete Model Analysis of Elastic-Plastic Plates", Journal of Engineering Mechanics Division, ASCE, Feb. 1968, pp. 271-293.

[4] P.V. Marcal, "A Stiffnes Methods for Elastic Plastic Problems", International Journal of Mechanics and Science, vol. 7, 1965, pp. 229-238.

[5] D.C.A. Koopman and R.H. Rance, "Oo Linear Programming and Plastic Limit Analysis", Journal of Mechanics and Physics of Solids, 1965, vol. 13, pp. 77-87.

[6] Takeo Mori, “Numerical Analysis of Elastic-Plastic Plates", Thesis for Master of Engineering, submitted to Kyoto University, March, 1968. 


\section{単純支持弾塑性平板の数 值解析 ${ }^{11}$ (梗概)}

$\begin{array}{ccccl}\text { 正会員 } & \text { 横 } & \text { 尾 } & \text { 義 } & \text { 貫* } \\ \text { " } & \text { 中 } & \text { 村 } & \text { 恒 } & \text { 善** } \\ & \text { " 森 } & & \text { 武 } & \text { 雄*** }\end{array}$

\section{1. 緒 言}

塑性平板の研究は，大きく2 種類に別けられる。極限 解析においては, 完全解は崩壊荷重と, 崩壊時のモーメ ント場および変位速度場からなる。これに対して弾塑性 解析は, 荷重の変動に伴らモーメント場之変位場の变化 を追跡するものである。

本論は，単純支持長方形板の弾塑性変形性状を数值解 析によって追跡解明しようとするものである。非軸対称 板の弾塑性解析における最大の困難は，未知弾塑性境界 と基礎方程式の非線型性にある。それ故に既往の研究は 円板に限られていたが，本研究遂行中に，正方形板につ 认て Bhaumick and Hanley [2] の数傎解析結果が発表 され，続いて本研究終了時に Ang and Lopez [3]の数 值解析結果が提出された。[2] は歪增分理論による解析 かどらか不明であるのに対し，[3] は板要素をモデル化 して歪増分理論を適用している。本論では基礎微分方程 式系を直接差分式に置換し歪増分理論を適用しているの で誘導過程は [3] と異なりまた [3] のモデル化のパ ラ.メーターのために, その数值解析結果と本研究の結果 を直接比較する事 は困難である。更に [3] が正方形板 のみを扱うのに対し，本論は長方形板について，その弾 塑性性状が如何に変化するかを解明するむのである。

\section{2. 増分形式の基礎方程式亡対応する差分方程式}

次の仮定に基いて解析を行なう。

(i ）モーメント曲率関係は歪増分理論に基く。

(ii) 断面は降伏しているか，弾性城にあるかのいず れかである。これは，サンドイッチ断面を考えることに 相当する。

(iii） 微少変形とし, 面内力は無視する。

(iv）モーメント場，変位場は 2 階連続微分可能であ るとし，また理論的に可能な塑性域でのモーメントの不 連続については，平均化，平滑化して近似され得るもの とする。

座標系は図一1 に示されるように選ぶ。式 (1) で定 義される無次元化量を用いる。ミーゼスの降伏条件は式 (2) で与兄られる。曲率 $k_{x}$ 等は, 弾性歪 $k_{x}{ }^{e}$ 等と塑 性歪 $h_{x}{ }^{p}$ 等の和として表わされる。塑性法則 は条件式

1）昭和 43 年 5 月近織支部研究会で発表したものである

* 京大教授 $\quad * *$ 同助教授 $* * *$ 同防災研助手 (昭和 43 年 5 月 29 日本稿受理, 討諭期限昭和 44 年 1 月末日)
（4）のむとで, 式 (3) で表わされる。以下“4”は各 量の増分を表わすものとする。歪増分は，式（5）のよ らに表現され得る。式 (5) の逆変換は式 (4)を用い て, 式 (6) のように表わされる。“ “ $4 \mu ”$ はモーメント とは異なった量であるが，便宜上この列をも stiffness matrix $\left[S_{i j}\right]$ に含めることとする。 $\left[S_{i j}\right]$ は弾性応答, 塑性応答各々に対して，式 (7) の内容を有する。

增分形式で表わされた釣合式 (8) を階差式表示し たものが式 (9) である。ここに $\delta_{x}=\alpha \delta_{y}$ であり， $\delta_{x}$ ， $\delta_{y}$ は各々 $x, y$ 方向の格子間隔を表わす。歪変位関係 の増分形式 (10) を階差式表示すると式 (11) を得る。 単純支持辺の場合の境界条件は式 (12) で与えられる。 これは降伏以前，以後ともに $x=$ const. で $\Delta w=0$, $\Delta k_{x}=0$ となる事が証明される。故に境界条件の階差式 は式 (13) で与えられる。隅点に対しては，近傍での checker board 型変形を仮定して式（14）を用いる。

式 (6)，（9），(11）は，境界条件式 (13)，(14）と ともに，ある状態のモーメント分布に基いて，これに近 以次の荷重状態に対する $\Delta w(i, j)$ に関する連立一次方 程式系を構成する。故に，適当な荷重増分に関する数值 積分が繰り返されれば，板の弹塑性変形が追跡されるこ ととなる。

\section{3. 数值計算法}

荷重の上昇に伴い，塑性格子点数は徐々に増加する。 即ち, 荷重変化にともなう塑性域の桩大が，数值計算解 の一部として得られる。

各格子点はそれぞれ異なる荷重值において弾性から塑 性へ移る。前以て定められた何重增分に対する各格子点 の応答が，その荷重増分全量に対して弾性応答となる か, 部分的に塑性応答となるかは，あらかじめ解ってい ない。故に，部分的な塑性応答の起ることがなく，しか も前段階の弾性格子点が少なくとも 1 ケ丁度降伏するよ うに荷重増分を定めることとする。 $m_{x}(i, j, n)$ 等を $n$ 段階最終のモーメントとし,$\Delta m_{x}(x, j, n+1)$ 等を $n+1$ 段階での単位荷重増分に対するモーメント増分とする と, 格子点 $(i, j)$ が降伏するのに必要な荷重増分 $\overline{\triangle p}$ $(i, j, n+1)$ は (15) 式上り求められ, $\Delta p(n+1)$ は $\overline{\Delta p}(i, j, n+1)$ の最小值として定められる。

数值計算の 1 段階は以下より成る。

(i) $n$ 段階のモーメント最終值により各格子点の 
stiffness matrix を定める。

(ii) $\Delta w(i, j)$ に関する階差式の係数を定める。

(iii) $\Delta p=1$ に対して連立一次方程式を解き $\Delta w(i, j)$ を求める。

(iv） 各格子点について $\Delta \mu(i, j)$ を求め, $\Delta \mu(i, j)$ $<0$ となる格子点があれば， $\Delta \mu(i, j)$ が最小值となる 点の塑性 stiffness matrix を弾性のものに改め, (ii) に もどる。

（v）すべての格子点に対して $\Delta \mu(i, j) \geq 0$ であれ ば，式 (15) に従い $\Delta p(n+1)$ を定める。

（vi） $\Delta p(n+1)$ に対するモーメント増分を求め，こ れを $n$ 段階最終モーメントに加え, $n+1$ 段階最終モー メントを得る。

\section{4. 計 算 結 果}

$C=1.0, \nu=0.3$ とし, 辺長比 $1 / \alpha=1,2,4$ の場合に ついて計算を行なった。格子はいずれの場合も 5 等分で ある。図一2 は若干の格子点についての荷重変位曲線で ある。破線 I，II は，[5]により提案されたりニヤプ ログラミングを適用する方法により得られた，トレスカ の降伏条件に従う，対応寸る長方形板の崩壊倚重の下界 である。図一 3 は $1 / \alpha=2$ の板の単位荷重による， $x$ 軸, $y$ 軸上の点の暁み曲線である。塑性格子点の増加にとも なう板全体の曲げ剛性の低下が明らかである。

図一4 は格子点の降伏の順序を示す。 $1 / \alpha=2,4$ の場 合は部分的除荷応答は結果として生じなかった。だが正 方形板において，6段階目 $(0,0)$ 点で，9，10段階 目 $(0,1) ，(1 ， 0)$ 点でそれぞれ部分的除荷応答が結果 として得られた。この場合降伏関数は計算上の許容範囲 としておいた -0.01 以下となることはなかった。正方 形板において塑性域梳隅点から，ついで中央点から刘角 線上へと拡がるが， $1 / \alpha=2 ， 4$ の長方形板においては中 央点から長手方向へ拡がり，ついで隅点から搪がってく る塑性域とつながる。[3] によると，正方形板において は対角線上に塑性域がつながり，pseudo-mechanism が 形成される時，板全体の曲げ剛性が急速に低下寸るとい らことであるが，図一2，図一3 からみられるとおり， 長方形板においては中央部に带状の塑性城が形成された 段階で既に，板全体の曲げ岡性はかなり低下する。
格子点のモーメント状態を $\left(m_{x}, m_{x y}, m_{y}\right)$ 空間の像 としてみた時，これを忍力点と称する。図一 5 は $1 / \alpha=2$ の場合の $p=0.473$ (弾性限), $p=0.591$ における応力 点を連ねた図, 応力図を示す。荷重の増大にともない応 力図が膨張し降伏曲面に接近する様子がみられる。図一 6 , 図一7 は各々 $1 / \alpha=1,2$ の場合の, 常に $m_{x}=m_{y}$ も しくは $m_{x y}=0$ が成立する格子点の stress-path を示 す。

格子分割の影響を調べるために， $1 / \alpha=2$ の場合を対 象とし，4，5，6 等分格子に対する数值解が得られた。 図は中央点の荷重変位曲線の, 図一9 は定荷重值にお打 る塑性域の格子分割による差異が比較されている。大き な差異のないことがみられる。

\section{5. 結 論}

（i ）板の弾塑性変形の逐次数值解析方法が，十分良 好な収束性を持って，示された。

(ii）正方形板においては塑性域はむず隅点から，そ の後中央点からも拡がり，対角線上に進んでいく。とこ ろが長方形板ではまず中央から長手方向に塑性域は拡が り，あるところで喁点方向に向い，隅点から搪がってき た塑性域とつながる。

(iii）長方形板の板全体としての曲げ岡性は, 中央点 長手方向に帯状の塑性域ができた段階でかなり低下す る。弾性限から, 板全体の曲げ剛性が十分低下寸るまで の荷重増分は，板の形状が細長くなるに従い小さくな る。

(iv) 正方形板においては, 各応力点は降伏後 $m_{x y}$ が減少し， $m_{x}+m_{y}$ が増加する方向に降伏曲面上を移動 する。長方形板に执いては, 対角線に関して短辺側三角 形内の応力点は比較的急速に降伏曲面に達し, 降伏後 $m_{x y}$ が減少， $m_{x}+m_{y}$ が増加する方向に降伏曲面上を 移動するが，長辺側三角形領域内の応力点は比較的緩慢 に降伏曲面に接近する。

\section{6. 謝辞}

数值計算は京都大学計算センター KDC-II によっ た。数值計算にあたり終始助言をいただいた松永裕之氏 に感謝します。 


\title{
SYSTEMATICAL ANALYSIS AND NUMERICAL EXAMPLES ON THE PLASTIC COLLAPSE AND THE BUCKLING COLLAPSE OF ELASTIC PLASTIC FRAMES (In the Case of no unloading) (1)
}

by TOSHIO SATO, Assistant Prof. of Nihon Univ. TOSHIO HANNUKI, Assist. of Nihon Univ., MASAKAZU KOGA Graduate Student, of Nihon Univ. Members of A.I.J.

One of the present authors has been studied numerically the interaction curves taking account of the bucklbending (bending under the beam-column effect) on the plastic collapse and the buckling collapse by M. Kuranishi in the case of the unbraced multi-story frames with the initial plastic hinges to be formed at the base of columns. On the other side, the buckling behavior of unbraced frames resach has been so developed that plastic design metohd was prepared as the lecture note at the Lehigh Univ. and others. The most of them were presented as the approximate design methods without buckling collapse that presumed ultimate load by the iterative procedure or compatibility analysis etc. However, in this paper, present authors proposed the systematical analysis method under the assumption to given virtical loads and fixed critical sections at a given place of yield hing in order to treated the ultimate lateral loads in cluding the buckling collapse as a whole of frames. Then, the main paints of our procedure were much the same as the compatibility analysis to expected that newly considered the criterion called the Feimberg's Stability Condition. Finally, the unbraced 1 bey 2 story frames were innestigated as numerical examples.

U.D.C. 624.073.043

\section{NUMERICAL ANALYSIS OF ELASTIC-PLASTIC DEFORMATION \\ OF SIMPLY SUPPORTED RECTANGULAE PLATE (See Page 27)}

by Dr. YOSHITSURA YOKOŌ, Prof. Univ. of Kyoto, TUNEYOSHI NAKAMURA, Assis. Prof. Univ. of Kyoto, TAKEO MORI Graduate Student. of Univ. Kyoto, Members of A.I.J.

U.D.C. $624.075 .22: 625.043$

\section{AN ANALYSIS OF THE SPACE TRUSS BY STIFFENESS MATRIX USED LINEAR AND NON-LINEAR METHOD}

\author{
By Dr. HIROSHI KITAMURA, MIZUO YAMADA, TOKUYUKI \\ TAHARA and TUYOSHI TUJII. Taisei Construction Co. Ltd. \\ Membes of A.I.J.
}

In this papers, we analyse stress and deflection (strain), and behavior of buckling and vibration of spaced trussed members by finite deflection method.

The basic equation of this method is simply expressed by stiffieness matrix. In the basic equation of stress and deflection (strain), we have taken up next three methods, and compared each other.

1. Non-linear equation by finite deflection method.

2. Linear equation by finite deflection method.

3. Linear equation by general method.

For obtaining the basic equation of buckling and vibration by finite deflection method, we use linear method for simplification. In approaching this problem, we consider two cases, for spaced members with strain loaded and other without strain.

To add, in order to afford better understanding about several basic equations, we analyse a few simple examples.

U.D.C. 69.003 .12

\section{SEASONAL FLUCTUATION OF BUILDING STARTS BY TYPE OF OWNERS}

by RYOICHI SHIMADA, Assistant of Tokyo Metropolitan University, Member of A.I.J.

Pattern and stability of seasonal fluctuation of building starts are various by type of owners. Besides, the seasonal fluctuation pattern itself seems to change gradually. The pattern of "individual" is the most stable and "companies and other corporations" is the least. The pattern of individuals is significant. The peak comes in the summer and it does not change over the years. The pattern of "govermments" is also significant and the peak comes at the end of the year. The peak shifts during the former half of the period of analysis. The pattern of "companies" is not significant because of strong irregular factors. It also seems to have some tendency to shift to the opposite direction. The government and others are in a complementary relation imperfectly with each 